Authors: E Lombard and TR Carney

DIE WENSLIKHEID VAN AFRIKAANS AS VAKTAAL VIR REGSTUDENTE

ISSN 1727-3781

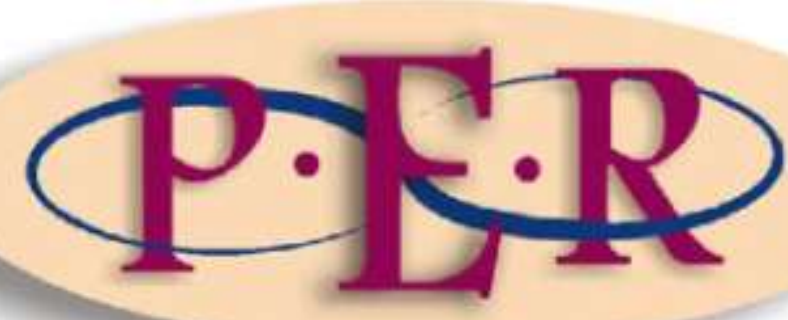

2011 VOLUME 14 No 1 


\title{
DIE WENSLIKHEID VAN AFRIKAANS AS VAKTAAL VIR REGSTUDENTE
}

\author{
Ellen Lombard* \\ Terrence R Carney**
}

\section{Inleiding}

Sedert die demokratiese verkiesing in 1994 en die bevordering van nege addisionele inheemse tale tot die status van ampstaal in die Handves van Regte soos vervat in die interim Grondwet ${ }^{1}$ en die latere 1996-Grondwet, ${ }^{2}$ naas Afrikaans en Engels, het Afrikaans as voertaal status begin verloor met die gevolg dat Engels as die lingua franca van Suid-Afrika uittroon. Wat sake selfs gunstiger vir Engels ten koste van die ander ampstale maak, is die feit dat die 1996-Grondwet nie so voorskriftelik soos die 1983-Grondwet ${ }^{3}$ met betrekking tot die amptelike gebruik van die tale van SuidAfrika is nie. Derhalwe word die ampstale nie voldoende beskerm in hul funksie as regstaal nie en word Engels telkens verkies. Daar is uiteraard 'n groter aantal redes waarom Engels binne die regspraktyk veld wen. Die uiteinde van die saak is dat Regsafrikaans stelselmatig (maar aansienlik vinniger as wat meeste mense vermoed) afstuur op taal(self)moord. In die lig van Regsafrikaans se ongunstige posisie moet die vraag gestel word of dit nog sinvol is om 'n vak soos Regsafrikaans aan 'n tersiêre instansie te onderrig? Is dit nog hoegenaamd wenslik om Afrikaans aan regstudente te doseer? Waarom moet die behoud en voortsetting van Regsafrikaans as vak oorweeg word?

In hierdie bydrae word daar van die standpunt uitgegaan dat 'n geletterdheidskursus in Afrikaans steeds regstudente (en -praktisyns) van waarde kan wees. Die outeurs

Ellen Lombard. BA, BEd, MEd, DEd, Hoër onderwysdiploma. Senior lektor, Departement Afrikaans en Algemene Literatuurwetenskap, Fakulteit vir Geesteswetenskappe, Universiteit van Suid-Afrika.lombae@unisa.ac.za.

** Terrence R Carney. BA, HonsBA, MA, Hoër onderwysdiploma. Lektor, Departement Afrikaans en Algemene Literatuurwetenskap, Fakulteit vir Geesteswetenskappe, Universiteit van Suid-Afrika. carnetr@unisa.ac.za. 'n Woord van dank aan SP van Zyl en SP Lombard.

Grondwet van die Republiek van Suid-Afrika 200 van 1993.

Grondwet van die Republiek van Suid-Afrika, 1996.

Grondwet van die Republiek van Suid-Afrika 110 van 1983. 
betoog die wenslikheid (en selfs die noodsaaklikheid) van Regsafrikaans deur op die volgende aspekte te fokus:

- Die belangrikheid van taal in die regswêreld

- 'n Kort oorsig van die geskiedenis van Regsafrikaans

- Anglisering binne die regspraktyk

- Engels as enigste notuleringstaal

- Die wenslikheid van Regsafrikaans

\section{Die regspraktisyn as taalpraktisyn}

Kommunikasie staan sentraal in die regspraktyk, soos dit ook die geval is op menige ander terrein. Malan ${ }^{4}$ wys daarop dat alle dienslewering in die een of ander taalmedium geskied en dat dit inherent aan taal gekoppel is. Sonder kommunikasie via taal (watter vorm die taal ook mag aanneem), is dienslewering eenvoudig nie moontlik nie. Taal en die regte het van meet af ' $n$ komplekse verhouding en is dikwels onlosmaaklik van mekaar. ${ }^{5}$ Soos Viljoen ${ }^{6}$ dit stel: "Reg is taal. Wie toegang tot die regsproses soek, moet woorde hê of vind." Die reg is in talle opsigte 'n produk van taal en stel nog altyd spesiale eise aan taalgebruik en -ontwikkeling. ${ }^{7}$ Taal kan in sommige situasies nie ontwikkel of voortleef sonder die bestaan en beskerming deur wetgewing nie en die regte kan nie bepaalde (illokusionêre) handelinge uitvoer sonder die gebruik van taal nie. As die regter nie die woorde tydens sy/haar uitspraak uiter nie, sal 'n misdadiger nooit gevonnis word nie. Taal is die werksinstrument waarmee regsgeleerdes hulle van hul taak kwyt. ${ }^{8}$ Die ganse regspraktyk word deur taal en kommunikasie geraak: onder meer akademiese artikels, kontrakte, dagvaardings, lasbriewe, beëdigde verklarings, testamente, pleitstukke en regters se uitsprake. "Language is indeed fundamental to the legal profession...". 9

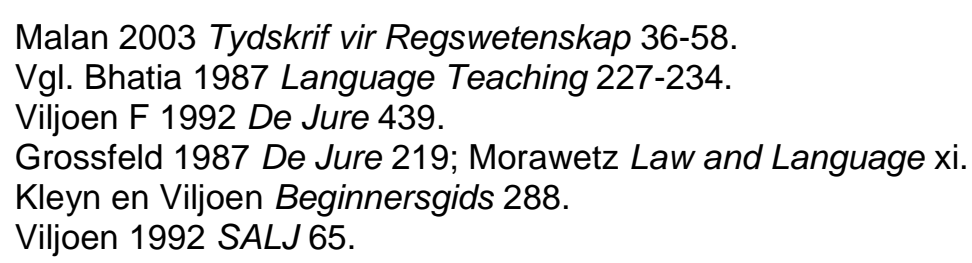


Regsgeleerdes se lewensbestaan is afhanklik van hul taalvaardigheid en daarom word daar van diesulkes verwag om dié vaardighede te verwerf, aldus Taylor. ${ }^{10}$ Dit is te betwyfel of enige regsgeleerde wat sy/haar sout werd is die noodsaaklikheid, afhanklikheid en impak van taal op sy/haar beroepswêreld sal onderskat of ontken. In die woorde van Morawetz: ${ }^{11}$ "Given the fact that law consists in specialised linguistic usages, one must assume that those trained in law have always been selfconscious about language." Die regspraktisyn is daarom by implikasie ook taalpraktisyn.

In die regswêreld moet daar so versigtig en duidelik moontlik met taal omgegaan word. 'n Gebrek aan korrekte en eenduidige formulering kan tot interpretasiemoontlikhede lei en komplikasies en skuiwergate veroorsaak; gevolglik kan foutiewe formulering veroorsaak dat wetgewing ongeldig verklaar word. ${ }^{12}$ Kontrakte kan byvoorbeeld ongeldig verklaar word omdat die uitleg daarvan onmoontlik geword het as gevolg van swak taal. ${ }^{13}$ Die prokureur kan selfs verantwoordelik gehou word vir die regsaanspreeklike gevolge wat voortspruit uit verkeerde taalgebruik en kan van die rol geskrap word. ${ }^{14}$ Goeie taalgebruik en begrip is daarom van kardinale belang aangesien slordige taalpraktyk finansiële en regsimplikasies kan hê. Regstaal kan egter tot kopsere lei weens die argaïse en komplekse jargon (ook bekend as legalese) wat dié terrein kenmerk. Dit het dikwels tot gevolg dat Jan Publiek uitgesluit word en van die regsgeleerde vir interpretasie en bemiddeling afhanklik is. Dit roep die verhouding tussen die geleerde priester en sy ongeletterde gemeentelede in die Middeleeuse kerk in herinnering.

Soos dit die geval is met meeste vaktaaldissiplines, is regstaal dikwels ondeurdringbaar en eksklusief. Taylor ${ }^{15}$ verwys na die regstaal as ' $n$ vreemde of selfs addisionele taal; ' $n$ sentiment wat waarskynlik deur ' $n$ aantal regs- en

\footnotetext{
Taylor 1998 THRHR 668.

Morawetz Law and Language xi.

Vgl. Interpretasiewet 33 van 1957.

Vgl. Christie Law of Contract 219.

Vgl. Wet op Prokureurs 53 van 1979.

Taylor 1998 THRHR 669, 670.
} 
taalkenners geëggo sal word. Om die brug tussen die leek en die juridiese kosmos ${ }^{16}$ te slaan, is die rol van die regspraktisyn as taalpraktisyn dus steeds belangrik.

Binne die Suid-Afrikaanse regsdomein staan Afrikaans en Engels sentraal. Hoewel Regsafrikaans tans in 'n ongunstige en benadeelde posisie verkeer, het dié vaktaal 'n aangrypende geskiedenis wat die verhaal van verskeie pioniers en hul taalstryd vertel. Vervolgens 'n kort oorsig.

\section{Historiese agtergrond van Afrikaans as regstaal}

Die geskiedenis van Afrikaans as regstaal het sy ontstaan in die vroeë twintigste eeu en gaan gepaard met verskeie politieke en sosiokulturele verwikkelinge. Met die stelselmatige opkoms van Afrikaner-Nasionalisme, die vertaling van die Bybel in 1933, en selfbeskikkingsreg vir Suid-Afrika weens die Statuut van Westminister, is dit in terugskou nie vreemd dat Afrikaans as regstaal na vore sou tree nie. Reeds so vroeg as 1920 het regsgeleerdes aan die Universiteit van Stellenbosch van Afrikaans as onderrigmedium in die doseer van regte gebruik gemaak. ${ }^{17}$

$\mathrm{Na}$ afloop van die eerste Afrikaanse hofuitspraak ${ }^{18}$ wat in 1933 gelewer is, dra ander verwikkelinge - soos die uitgee van 'n Engels-Afrikaans regswoordeboek ${ }^{19}$ en die hersiening daarvan in 1949 deur Hiemstra en Coertze - tot die bevordering van Regsafrikaans by. Daarna volg die stigting van Tydskrif vir Hedendaagse RomeinsHollandse Reg in 1937 gevolg deur die publikasie van L.C. Steyn se gesaghebbende bydrae, Uitleg van wette, ${ }^{20}$ in 1946. Figure soos appèlregter Frederik Willem Beyers het 'n belangrike rol gespeel deur Afrikaans as hoftaal in sy uitsprake en verslae te gebruik, hoewel die aanvanklike gebruik van Afrikaans in hierdie konteks sonder veel meriete hanteer is. In 1937 het Afrikaans selfs meer veld gewen toe 'n Engelssprekende regter, R.P.B. Davis, sy hofuitspraak in Afrikaans ${ }^{21}$ gelewer het. In

\footnotetext{
Vgl. Mgoduso 1999 De Rebus 8-9.

Van der Merwe 1975 Nuntius 8-10.

Souter v Norris 1933 AD 41.

Van Zijl Steyn Engels-Afrikaanse Regswoordeboek.

Steyn Uitleg van Wette.

Lategan v Union Government 1937 CPD 197.
} 
1965 is ' $n$ handboek met die hofreëls in Afrikaans uitgegee. ${ }^{22}$ Verskeie ander nodige handboeke sou volg. Hiemstra ${ }^{23}$ meen dat drie faktore ' $n$ wesenlike uitwerking op die Afrikaanse regspraktyk gehad het, naamlik die aanstelling van Afrikaanssprekende regters, die toename in Afrikaanse advokate en die reëlmatige uitgee van handboeke in Afrikaans. Volgens Hiemstra het dit aanleiding gegee tot die groei in gerapporteerde hofuitsprake in Afrikaans: $4.47 \%$ in 1948 en 27\% in 1968. Die groei van Regsafrikaans het in die sewentiger- en tagtigerjare toegeneem, maar beleef helaas sedert die negentigerjare ' $n$ afname. Ter illustrasie: Die Tydskrif vir Regswetenskap (wat as 'n Afrikaanse joernaal begin het) het tussen 2001 en 2009 twintig uitgawes gepubliseer. Die getal Engelse artikels gedurende die vermelde tydperk beloop 116 artikels. Slegs 47 artikels het in dié tyd in Afrikaans verskyn; drie uitgawes (2003, 2004 en 2006 onderskeidelik) bevat geen Afrikaanse artikels nie en sewe uitgawes het slegs een artikel elk wat in Afrikaans verskyn het. Die Tydskrif vir Suid-Afrikaanse Reg het tussen 2003 en 2010 'n totaal van 32 uitgawes gepubliseer waarvan 228 artikels in Engels en 87 in Afrikaans verskyn het. Twee uitgawes bevat geen Afrikaanse artikels nie, terwyl drie uitgawes slegs een Afrikaanse artikel elk bevat.

Dit is belangrik om te onthou dat die uitgee van sulke tekste baanbrekerswerk was en dat dit voldoen het aan 'n groeiende behoefte. Deur Afrikaanse uitsprake te lewer en dit te notuleer, handboeke uit te gee, akademiese artikels in Afrikaans te publiseer en in die loop van tyd ook regskursusse aan te bied met Afrikaans as onderrigtaal, het dit 'n gesonde en geil teëlaarde geskep vir Afrikaans om as regstaal te groei en te ontwikkel. Later het die Departement van Justisie en verskeie baanbrekers waardevolle bydraes gelewer om Afrikaans volledig uit te bou tot regstaal wat aan tersiêre instellings gedoseer is (en later deur wetgewing afgedwing is $)^{24}$ en ook in die howe en privaat praktyke gebesig is.

Die bydrae wat universiteite in Suid-Afrika tot die Afrikaanse regspraktyk gelewer het, is onontbeerlik. Regskursusse aan die historiese Afrikaanse universiteite is in Afrikaans uitgebou - soveel so dat enige van die spesialisgebiede in die regsleer in

Nathan, Barnett en Brink Reëls en Gebruike van die Hooggeregshof.

Hiemstra 1970 Tydskrif vir Geesteswetenskappe 251-263.

Hiemstra 1970 Tydskrif vir Geesteswetenskappe 256. 
Afrikaans gevolg kan word. Die belang van goeie kommunikasievaardighede en die behoorlike beheersing van regstaal, en dan ook Regsafrikaans, het aanleiding gegee tot die ontstaan van geletterdheidskursusse wat daarin gespesialiseer het om die student van 'n grondige regstaalkennis te voorsien en hom/haar in staat te stel om die reg in Afrikaans te pleeg. Die kursusse het aanvanklik ten doel gehad om onder meer Latynse terme, argumentasie en redenasie (retoriek), sinsformulerings, teksstruktuur en redigering met studente te behandel. Die kerninhoud is universeel en kom in byna elke regstaalkursus voor. Geletterdheidskursusse (of variasies daarvan) in Regsafrikaans word tot op hede steeds aan die Universiteit van SuidAfrika, die Universiteit van Johannesburg, die Universiteit van die Vrystaat en die Noordwes-Universiteit gedoseer. Dit is hierdie geletterdheidskursusse in Regsafrikaans wat in dié bydrae betrekking het.

Die keuse van Regsafrikaans bo Regsengels hou sterk verband met die Afrikaanssprekende individu en sy/haar regstaalbehoeftes, asook die regstudent se keuse om in Afrikaans onderrig te word. Maar die spoedige verengelsing sedert die demokratiese verkiesing in 1994 doen sigbaar afbreek aan die (voor)reg om in Afrikaans te studeer en te praktiseer.

\section{Die huidige situasie van verengelsing}

Suid-Afrika het na 1994 wegbeweeg van 'n streng voorskriftelike taalbestel. Wanneer die taalbepalings van die 1983-Grondwet en dié van die 1996-Grondwet vergelyk word, is dit nie net opvallend dat daar nou elf in plaas van twee amptelike tale op nasionale vlak is nie, maar ook dat daar ná 1996 wegbeweeg is van streng voorskriftelike taalbepalings. Die beginsel van statutêre tweetaligheid, asook taalgelykberegtiging is laat vaar:

Generally speaking, it is probably correct to state that the evolving pattern of official language policy in South Africa reveals a trend towards English, thus in effect towards official monolingualism. ${ }^{25}$

25 Du Plessis en Pretorius 2000 SA Public Law 506. 
Daar word tans in artikel 6(3) van die 1996-Grondwet slegs die minimum vereiste gestel dat die regering sake in ten minste twee amptelike tale sal voer. Daar word nie voorgeskryf watter twee tale gebruik moet word nie. Strydom en Pretorius kom in hulle analise van die 1996-taalartikel tot die gevolgtrekking dat die gebrek aan voorskriftelikheid nie 'n vergunning is om die grondwetlike taalbepalings te omseil nie:

(N)o organ of state may aproach section 6 with the sole motive of finding loopholes in it only to justify its lack of commitment to overcoming the practical problems encountered while striving for the realisation of the constitutional directives of parity of esteem and equitable treatment of all official languages, as well as the development of the neglected indigenous languages. ${ }^{26}$

Sedert 1994 is daar wat die taal van wetgewing betref, die neiging om streng voorskriftelikheid rakende die gebruik van die amptelike tale te vermy. Hierdie toegeeflike benadering het tot gevolg dat Engels die dominante taal van SuidAfrikaanse wetgewing geword het. Malan ${ }^{27}$ se ondersoek na die taal van wetgewing bevestig dat dit tot nog onlangs die gebruik was dat parlementêre tradisie bepaal het dat waar Engels die amptelike teks is, die tweede teks in Afrikaans sal wees. Die tweede teks kan wel in enige van die ander amptelike tale vertaal word.

Die heersende geskil oor nasionale taalwetgewing in Suid-Afrika bevestig dat dringende ingryping en strategiese planne in plek gestel moet word vir die behoud en bestendiging van Afrikaans as onderrigtaal en die uitbou van die inheemse tale. Hierdie geskil handel oor 'n nasionale taalwet handel oor artikel 6(4) van die 1996Grondwet:

Die nasionale regering en provinsiale regerings moet deur wetgewende en ander maatreëls hul gebruik van amptelike tale reël en monitor. Sonder afbreuk aan die bepalings van subartikel (2) moet alle amptelike tale gelykheid van aansien geniet en billik behandel word. Subartikel (2) bepaal verder: Gesien die historiese inkorting van die gebruik en status van die inheemse tale van ons mense moet die staat praktiese en daadwerklike maatreëls tref om die status van dié tale te verhoog en hul gebruik te bevorder. $^{28}$

Strydom en Pretorius (sien Du Plessis 2010 www.oulitnet.co.za).

Malan 2009 www.vrs.co.za.

Grondwet van die Republiek van Suid-Afrika, 1996. 
'n Nasionale taalwet is reeds ' $n$ geruime aantal jare in die vooruitsig gestel en ' $n$ wetsontwerp (South African Languages Bill) ${ }^{29}$ het die lig gesien en sou op 24 September 2000 - Erfenisdag - amptelik deur die Departement van Kuns, Kultuur, Wetenskap en Tegnologie aan die kabinet voorgelê word. Die wetsontwerp, wat op 24 April 2003 finaal hersien is, is egter deur die Mbeki-regering laat vaar. Die beplande Suid-Afrikaanse taalwet sou die eerste amptelike poging wees om ' $n$ definitiewe taalbeleid na 1994 daar te stel. Weens hierdie leemte duur die verwaarlosing van al die landstale behalwe Engels voort, ten spyte van teenkanting vanuit onder andere Afrikaanse geledere. ${ }^{30}$

Die gebrek aan ' $n$ nasionale taalbeleid en die regering se traagheid het tot ' $n$ ingrypende hofsaak, Lourens $v$ die President van die Republiek van Suid-Afrika, ${ }^{31}$ aanleiding gegee. Cornelus Lourens het ' $n$ saak teen die President, die Minister van Kuns en Kultuur en die Minister van Justisie aanhangig gemaak waarin Lourens die regering wil dwing om hul grondwetlike plig rondom 'n nasionale taalbeleid na te kom. ${ }^{32}$ Lourens wil onder meer verseker dat Afrikaans, asook al die ander ampstale wat tans ondergeskik is aan Engels, hul regmatige plek inneem en Engels se dominansie aan bande lê. ${ }^{33}$ Die hofuitspraak van regter Du Plessis in casu het tot gevolg dat die regering by name van die Minister van Kuns en Kultuur, binne twee jaar vanaf die datum van bevel moet toesien dat artikel 6(4) van die Grondwet nagekom word, hetsy deur middel van wetgewing of ander amptelike maatreëls. ${ }^{34}$

Dié beslissing van die Noord Gauteng-Hooggeregshof het 'n aantal implikasies tot gevolg waaronder ' $n$ beduidende invloed op taalgebruik in die regspraktyk. Die voorkeur aan onder meer Engels as notuleringstaal in Suid-Afrikaanse howe mag dalk binne die volgende twee jaar die nekslag toegedien word. Maar tans lyk die

South African Languages Bill - AK 1514 in SK 24893 van 30 Mei 2003.

Rademeyer Beeld 15.

Lourens v die President van die Republiek van Suid-Afrika (49807/09) [2010] ZAGPPHC 19 (16 Maart 2010).

32 De Bruin 2010 www.nuus24.com.

33 Sien Du Plessis vir 'n breedvoerige ontleding van die betrokke nasionale taalwet: Du Plessis 2010 www. oulitnet.co.za.

34 Lourens $v$ die President van die Republiek van Suid-Afrika (49807/09) [2010] ZAGPPHC 19 (16 Maart 2010). 
situasie geensins bemoedigend nie en heers daar 'n benoudheid dat Engels se invloed (en uitwerking) reeds te ver strek. Die status van 'n taal binne die regsdomein word meestal deur die taal se gebruik as notuleringstaal bepaal. Dit lê voor die hand dat Engels as die enigste taal van rekordhouding negatiewe gevolge vir Afrikaans, en spesifiek Regsafrikaans, inhou.

\section{Engels as enigste notuleringstaal - die implikasies vir Afrikaans as regstaal}

Afrikaans word in Suid-Afrikaanse howe gebruik as medium van getuienis (niejuridies van aard) oor gebeure buite die hof wat tot die hofverrigtinge gelei het, asook as regstaal (die medium van die juris; die taal waarin die reg kan funksioneer). Dit kan omomwonde gestel word dat die belangrikste funksie van Afrikaans as regstaal die gebruik van Afrikaans as notuleringstaal (taal van rekord) van hofverrigtinge is. Die notuleringstaal is die amptelike taal van die hof waarin die hofverrigtinge opgeteken word en waarin die hof uitspraak lewer.

Alhoewel beide Afrikaans en Engels steeds as notuleringstaal gebruik word, het die Minister van Justisie, asook regeringwoordvoerders, reeds te kenne gegee dat 'n eentalige Engelse stelsel vir die notulering van hofverrigtinge ingevoer mag word. ${ }^{35}$ (In sekere opsigte druis hierdie oorweging in teen artikel 9(3) en artikel 30 van die ${\text { Grondwet }{ }^{36} \text {. Hoewel Heuth }}^{37}$ argumenteer dat die eerdtydse status quo van hoërfunksietale (Afrikaans en Engels) teenoor laerfunksietale (die nege inheemse ampstale) sedert 1994 geensins verander het nie, is daar tog 'n sigbare agteruitgang van Afrikaans ten spyte van sy hoërfunksiestatus wat aan dié taal se gebruik as notuleringstaal gekoppel kan word. Afrikaans as notuleringstaal vra nie om afskaffing nie, maar verdien juis aktiewe bevordering om in hierdie proses ook die ander ampstale te verhef.

\footnotetext{
35 Dit was egter die geval vóór die uitspraak in Lourens $v$ die President van die Republiek van SuidAfrika.

Grondwet van die Republiek van Suid-Afrika, 1996.

Heuth "Disabling and Enabling" 331.
} 
Malan $^{38}$ wys op die volgende implikasies van die wegdoen van Afrikaans as notuleringstaal:

- Afrikaans as regstaal word ingeperk en Afrikaanse regslui word gevolglik weerhou van voortgesette instandhouding van Afrikaans as regstaal.

- Afrikaans word gereduseer tot die taal waarin getuienis afgelê word en dit sal 'n gewisse afname van regstudie en gevolglik publikasie en regsmateriaal in Afrikaans tot gevolg hê.

- Afrikaans en Engels is die enigste tale wat tans as notuleringstaal gebruik word. Indien slegs Engels vir notuleringsdoeleindes aangewend word, word Afrikaanse regstaal vir benadeling uitgesonder, aangesien dit nie die ander minderheidstale raak nie.

- Engels as enigste notuleringstaal sal tot gevolg hê dat die probleem van oormatige vertaling slegs vererger, aangesien alle nie-Engelse getuienis (wat nou ook Afrikaans insluit) voortaan oorgetolk sal moet word.

- Groter druk sal op Afrikaanssprekendes geplaas word om eerder in Engels te getuig, aangesien die notuleringstaal slegs Engels is.

- Afrikaans is die beste presteerder onder inheemse tale om meertaligheid ${ }^{39}$ te bevorder. Indien Afrikaans die funksie van notuleringstaal moet inboet, verskraal die moontlikheid dat die ander inheemse tale ooit hierdie hoër taalfunksie sal verwerf. Die moontlike groei van al die inheemse tale word dus gekortwiek. $^{40}$

As die verheffing van Engels as enigste notuleringstaal voortgesit word - en die regering sloer om Du Plessis $\mathrm{R}$ se beslissing (supra) gestand te doen - sal die motivering om 'n kursus in Regsafrikaans aan te bied, uitdagender word. Daar word van die standpunt uitgegaan dat só 'n kursus om 'n verskeidenheid redes steeds wenslik is.

38 Malan 2003 Tydskrif vir Regswetenskap 56.

39 Meertaligheid verwys in dié bydrae na drie of meer tale en word derhalwe onderskei van tweetaligheid.

40 Sien Phaalha en Cote vir verdere bespreking aangaande die benadeelde posisie van die nege inheemse ampstale, veral met betrekking tot taalgebruik binne die regspraktyk, spesifiek binne die hof: Phaalha "Knowledge Production" 142-154; Cote Right to Language. 


\section{Betoog: die wenslikheid van 'n kursus in Regsafrikaans}

Die stryd om die behoud van Afrikaans en die regte van die taal op ' $n$ verskeidenheid terreine, is alombekend. 'n Mens hoef bloot die pers te volg om kennis te neem van 'n taalstryd wat binne skoolsale en op universiteitskampusse woed. ${ }^{41}$ Taalstryd en aktivisme is ' $n$ bekende verskynsel onder Afrikaanse geledere. Soos Cunningham ${ }^{42}$ dit stel: "In some countries, the value of languages and the belief in multilingualism are integral to the ethos of a nation." Dit is kenmerkend van Afrikaanssprekendes en hul houding teenoor hul taal. Hoewel die behoud van 'n kursus in Regsafrikaans aan taalregte gekoppel kan word, is dit te betwyfel of só 'n betoog veel sou vermag. Nóg die Suid-Afrikaanse regering nóg waghondinstansies soos Pansat het tot op hede daarin geslaag om die Grondwet na te kom en die bevordering en gelyke beregtiging van al elf ampstale te verseker. ${ }^{43}$ Engels geniet die voorkeur.

Daar heers globaal ' $n$ wanindruk dat die bevordering van en voorkeur vir Engels tot die opheffing van die individu sal lei en hom/haar noodwendig deur die poorte van welvaart sal neem. Sowel Webb ${ }^{44}$ as Koch en Burkett ${ }^{45}$ bied ' $n$ teenargument deur die voordele tot moedertaalonderrig en veral die bevordering van Afrikatale as teenpool tot Engels voor te hou. Hoewel Heugh ${ }^{46}$ 'n voorstander van (Engels-) enkelmediumonderrig is, dui sy wel aan dat die oënskynlike voorkeur vir Engels inderwaarheid 'n mite in Suid-Afrika is. Om eenvoudig toegang tot ' $\mathrm{n}$ taal te hê, beteken nie dat dit inherent voordelig is nie; wat werklik saak maak, is wat 'n persoon met die taal kan dóén. ${ }^{47}$ ' $n$ Kursus in Afrikaans vir regstudente verrig ' $n$ aantal uiteenlopende funksies en juis dáárom is só ' $n$ kursus wenslik.

Soos reeds in onderafdeling 2 bespreek is, vereis suksesvolle regspraktisering dat die regsgeleerde op sy/haar voete kan dink en redeneer en dat hy/sy oor noukeurige

\footnotetext{
Vgl. Legalbrief Today 2009 www.legalbrief.co.za.

Cunningham 2001 Tydskrif vir Taalonderrig 203.

Perry 2004 Ethnicities 501-521; Truter 2006 Literator 135-156.

Webb 2006 Tydskrif vir Geesteswetenskappe 37-50.

Koch en Burkett 2005 South African Journal of Higher Education 1089-1107.

Heugh 2002 Perspectives in Education 177.

Pennycook 1998 Language Sciences 85, 86.
} 
skriftelike en/of mondelinge taalvaardighede beskik, aangesien die regspraktisyn se kernaktiwiteite (byvoorbeeld 'n konsultasie met 'n kliënt, die lewering van 'n pleidooi of 'n uitspraak, die kruisondervraging van 'n getuie of die opstel van 'n kontrak of testament) deur middel van gesproke of geskrewe taal plaasvind. ${ }^{48}$ Korrekte regstaal is immers ' $n$ instrument tot regsekerheid. Die meeste aktiwiteite in die regspraktyk word beoefen waar taal uitsluitlik die draer is.

Voornemende regspraktisyns raak vertroud met die speelveld van hul beroep deur byvoorbeeld die bestudering van regstekste, die aanhoor van hofsake, gesprekke met regsgeleerdes en die lees van akademiese regsartikels, regshandboeke, hofverslae en wette. Ehlers wys op die noukeurigheid en presisie wat die reg in hierdie verband vereis:

\begin{abstract}
Argumente wat gebruik word, moet steekhou; briewe en hofstukke moet duidelik en ondubbelsinnig wees; kontrakklousules moet volledig en logies waterdig wees. Behalwe vir die feit dat regsgeleerdes se werk dus volledig uit talige optrede bestaan, word daar ook nog besonder hoë eise aan hierdie taalprodukte gestel. Dit maak die nut van 'n module oor Regsafrikaans voor die hand liggend. ${ }^{49}$
\end{abstract}

Die module Afrikaans vir Regstudente (AFK1504) wat by die Universiteit van SuidAfrika aangebied word, vorm byvoorbeeld deel van die vereiste modules van die LLB-leerplan. Studente het 'n keuse tussen 'n kursus in Regsafrikaans en Regsengels. Grondige kennis van Afrikaans (minstens matriekvlak) word van studente verwag om die vermelde module suksesvol af te handel. Afrikaans vir Regstudente is 'n vaardigheidskursus wat teoretiese kennis oor regstaal verskaf met die uiteindelike doelwit om die student toe te rus om taalvaardighede in die regspraktyk effektief te kan beoefen. Die doelwit van hierdie kursus is nie om regskennis oor te dra nie, maar die klem val op taalvaardighede in die regsberoep en bied ondersteuning aan beide voornemende regspraktisyns en praktiserende regslui om die taalvaardighede wat hul beroep vereis, te bemeester.

\footnotetext{
$48 \quad$ Kleyn en Viljoen Beginnersgids 282.

49 Ehlers Afrikaans vir Regstudente vii.
} 
Die voorkoms van taalfoute in sowel studente as regslui se skryfwerk (byvoorbeeld werkopdragte en amptelike regsdokumente) beklemtoon verder die noodsaaklikheid van 'n kursus in Regsafrikaans. Die volgende voorbeelde dien ter illustrasie:

Enkele algemene taalfoute in werkopdragte:

\begin{tabular}{|c|c|c|}
\hline Foutiewe werkopdragsin & Verbeterde sin & Tipe taalfout(e) \\
\hline $\begin{array}{l}\text { Dit het veroorsaak dat die } \\
\text { transaksie in sy geheel as } \\
\text { abnormal geklassifiseer was en } \\
\text { regte of verpligtinge geskep het, } \\
\text { wat nie normaalweg tussen } \\
\text { persone wat onder uiterste } \\
\text { voorwaardes beding geskep } \\
\text { sou word nie. }\end{array}$ & $\begin{array}{l}\text { Dit het veroorsaak dat die } \\
\text { transaksie in die geheel as } \\
\text { abnormaal geklassifiseer is en } \\
\text { regte of verpligtinge geskep het } \\
\text { wat nie normaalweg tussen } \\
\text { persone }{ }_{2} \text { wat onder uiterste } \\
\text { voorwaardes beding geskep } \\
\text { sou word nie. }\end{array}$ & $\begin{array}{ll}\text { - } & \text { Foutiewe verwyswoord sy } \\
\text { - } & \text { Spelfout en foutiewe } \\
\text { - } & \text { Nassiewe werkwoord } \\
\text { kommas aan te dui - } \\
\text { veroorsaak } \\
\text { werkwoordopeenhoping }\end{array}$ \\
\hline $\begin{array}{l}\text { Ontoelaatbare } \\
\text { belastingvermyding het 'n groot } \\
\text { impak op die billikheid en } \\
\text { regverdigheid van die } \\
\text { belastingstelsel en doen dit } \\
\text { skade aan, wat dan 'n } \\
\text { kunsmatige opwaartse druk op } \\
\text { matginale koerse uitoefen. }\end{array}$ & $\begin{array}{l}\text { Ontoelaatbare } \\
\text { belastingvermyding het 'n groot } \\
\text { impak op die billikheid en } \\
\text { regverdigheid van die } \\
\text { belastingstelsel en dit } \\
\text { veroorsaak skade aan die } \\
\text { belastingstelsel wat 'n } \\
\text { kunsmatige opwaartse druk op } \\
\text { marginale koerse uitoefen. }\end{array}$ & $\begin{array}{l}\text { Tante Betje-styl: } \\
\text { woordordefout ná die } \\
\text { voegwoord en. Hierdie } \\
\text { taalfout is tipies van } \\
\text { Afrikaanse regstaal. } \\
\text { - Woordkeuse en invloed van } \\
\text { Engels (leksikale } \\
\text { anglisisme) } \\
\text { - Spelfout }\end{array}$ \\
\hline $\begin{array}{l}\text { In artikel } 103 \text { se geval moes die } \\
\text { hof bepaal het of die spesifieke } \\
\text { belastingpligtige, in die } \\
\text { spesifieke omstandighede, } \\
\text { betrokke geraak het by 'n } \\
\text { skema. }\end{array}$ & $\begin{array}{l}\text { In artikel } 103 \text { se geval moet die } \\
\text { hof bepaal of die spesifieke } \\
\text { belastingpligtige, in die } \\
\text { spesifieke omstandighede, } \\
\text { betrokke geraak het by 'n } \\
\text { skema. }\end{array}$ & $\begin{array}{l}\text { Foutiewe gebruik van die } \\
\text { modale werkwoord moes wat 'n } \\
\text { verkeerde betekenisnuanse tot } \\
\text { die hoofwerkwoord voeg. Die } \\
\text { werkwoord moes impliseer dat } \\
\text { die hof veronderstel was om 'n } \\
\text { aksie uit te voer, maar versuim } \\
\text { het om dit te doen. }\end{array}$ \\
\hline
\end{tabular}


Enkele algemene taalfoute in regsdokumente, byvoorbeeld 'n akte:

\begin{tabular}{|c|c|c|}
\hline Foutiewe aktesin & Verbeterde sin & Tipe taalfout(e) \\
\hline $\begin{array}{l}\text { Alle regte op minerale en } \\
\text { edelgesteentes met inbegrip } \\
\text { van alle regte wat by die } \\
\text { pagvry-grondbesitter berus om } \\
\text { hierna kan berus om te deel in } \\
\text { gelde wat moontlike aan die } \\
\text { Staat kan toekom. }\end{array}$ & $\begin{array}{l}\text { Alle regte op minerale en } \\
\text { edelgesteentes, met inbegrip } \\
\text { van alle regte wat by die } \\
\text { pagvrygrondbesitter berus, } \\
\text { behoort aan die Staat. }\end{array}$ & Lomp en onduidelike sin \\
\hline $\begin{array}{l}\text { Planne en spesifikasies van alle } \\
\text { geboue en van alle } \\
\text { veranderings of aanbouings aan } \\
\text { geboue moet ingedien word by } \\
\text { die plaaslike bestuur wat se } \\
\text { skriftelike goedkeuring gekry } \\
\text { moet word. }\end{array}$ & $\begin{array}{l}\text { Planne en spesifikasies van alle } \\
\text { geboue }_{2} \text { en van alle } \\
\text { veranderings of aanbouings aan } \\
\text { geboue }_{2} \text { moet ingedien word by } \\
\text { die plaaslike bestuur wie se } \\
\text { skriftelike goedkeuring gekry } \\
\text { moet word. }\end{array}$ & $\begin{array}{ll}\text { - } & \text { Foutiewe verwyswoord } \\
\text { - } & \text { Nalaat om parentese met } \\
\text { kommas aan te dui }\end{array}$ \\
\hline $\begin{array}{l}{[\ldots] \text { wat die eienaar van }} \\
\text { sodanige erf met 'n laer ligging } \\
\text { nodig mag vind om aan te lê of } \\
\text { te bou, om die watr wat Aldus } \\
\text { oor die erf loop af te voer. }\end{array}$ & $\begin{array}{l}\text { [...] wat die eienaar van } \\
\text { sodanige erf met 'n laer ligging } \\
\text { nodig mag vind om aan te lê of } \\
\text { te bou om die water wat oor die } \\
\text { erf loop af te voer. }\end{array}$ & $\begin{array}{ll}\text { - } & \text { Foutiewe kommagebruik } \\
\text { - } & \text { Spelfout } \\
\text { - } & \text { Woordoortolligheid }\end{array}$ \\
\hline
\end{tabular}

Aspekte wat in voorafgemelde module (en soortgelyke regstaalkursusse) behandel word, is onder meer die volgende:

- die inhoudelike en tegniese taalversorging van regstekste;

- regswoordeskat;

- die reg en argumentasie;

- drogredenasies;

- die struktuur van komplekse saamgestelde sinne;

- die werkwoord: tyd, passief en modaliteit;

- die samehang van teksstruktuur;

- eenvoudiger regstaal;

- die opspoor van regsboeke en -tydskrifte in die biblioteek; en

- die doeltreffende lees van hofverslae. 
Op die keper beskou is die belang van 'n kursus in Regsafrikaans (en regstaal in die algemeen) ' $n$ belangrike aanwins op sowel akademiese as beroepsvlak. Buiten die funksionele inhoud van ' $n$ kursus in Regsafrikaans, sal sodanige kursus ook tot die volgende kan bydra, naamlik: die bevordering van meertaligheid en die behoud van kulturele diversiteit; ' $n$ teenvoeter vir uitsluitlike gebruik van Engels en die beoefening van moedertaalonderrig. Elk van hierdie aspekte word vervolgens kortliks bespreek.

\subsection{Meertaligheid en kulturele diversiteit}

Die Suid-Afrikaanse kulturele diversiteit en meertaligheid is wat die land in baie opsigte uniek maak. Die opkoms van ' $n$ internasionale lingua franca - soos Engels het tot dusver ' $n$ beperkende uitwerking op taaldiversiteit gehad. ${ }^{50}$ Taal, en gepaardgaande variëteite, het 'n sleutelrol om in die bevordering van taal- en kulturele diversiteit te speel; "[e]ducation, communication and languages have never been more important, despite the explosion of knowledge in science, medicine and technology"51 (ons kursivering). Wanneer ' $n$ taal afgeskaal of agterweë gelaat word, is daar gewoonlik kultuurgoed wat ook langs die pad verlore raak. Dit gaan daarom nie alleen oor die (voor)reg om die taal van jou keuse in regsituasies te gebruik nie, maar sluit 'n ganse kultuur, erfenis en bestaansruimte in. 'n Kursus in Regsafrikaans lewer ' $n$ bydrae in die bevordering en handhawing van taal- en kultuurdiversiteit (wat gelykertyd die gebruik van die ander inheemse ampstale insluit), maar só 'n kursus help ook om die voortbestaan van Regsafrikaans te verseker. Dus is 'n wederkerige verhouding hier ter sprake.

Die doseer van Afrikaans vir regstudente bevestig die kritiese belangrikheid van taalidentiteit van die minderheidsgroepe en die gebruik van inheemse tale in SuidAfrika. May ${ }^{52}$ wys daarop dat taal in teorie slegs een van die vele bepalers van identiteit is, maar dat dit in die praktyk dikwels veel verder as identiteit strek. Hy skryf: "Indeed, this should not surprise us since the link between language and

Cunningham 2001 Tydskrif vir Taalonderrig 203, 204.

Cunningham 2001 Tydskrif vir Taalonderrig 201.

May 2000 Journal of Multilingual and Multicultural Development 373. 
identity encompasses both significant cultural and political dimensions." ${ }^{53}$ Tollefson onderskryf ook die belangrikheid van die erkenning van minderheidstale:

The struggle to adopt minority languages within dominant institutions such as education, the law, and goverment, as well as the struggle over language rights, constitute efforts to legitimise the minority group itself and to alter its relationship to the state. Thus while language planning reflects relationships of power, it can also be used to transform them. ${ }^{54}$

\subsection{Teenvoeter vir Engels}

Tans is die gebruik van Afrikaans tydens hofverrigtinge ${ }^{55}$ en as notuleringstaal nog die enigste konstante aanduiding dat meertaligheid in die juridiese kosmos bestaan. ${ }^{56}$ Malan ${ }^{57}$ argumenteer dat wanneer daar met Afrikaans weggedoen word die ander inheemse ampstale nie genoegsaam ontwikkel sal word om die hoër taalfunksies, soos in die regspraktyk vereis word, te bemeester nie. Met Afrikaans aan die voorpunt, kan meertaligheid in die regspraktyk seëvier en kan veral die medeampstale ' $n$ beter vastrapplek in die praktyk kry. Engels word immers nie uitsluitlik in die platteland of in townships gebruik wanneer die reg betrek word nie. Die doseer van 'n kursus in Afrikaans vir regstudente kan help om 'n teenvoeter vir die uitsluitlike gebruik van Engels daar te stel en moontlik selfs as voorbeeld dien vir regstaalkursusse in enige van die ander ampstale. Die voortgesette onderrig van Regsafrikaans aan tersiêre instansies is belangrik vir die bevordering van individualisme en die beskerming van minderheidsregte.

\subsection{Moedertaalonderrig}

As vreemde of addisionele (vak)taal val Regsafrikaans binne die domein van taalonderrig vir spesifieke doeleindes, oftewel Language for Spesific Purposes. ${ }^{58}$ Dié broodnodige vaktaal, wat gelyktydig met regstudies aangeleer behoort te word, eis

May 2000 Journal of Multilingual and Multicultural Development 373.

Tollefson Planning Language 202.

Vandag word daar wel tale soos Khosa, Zoeloe en Noord-Sotho in streekslanddroskantore gebruik. Sien Den Hartigh 2009 www.mediaclubsouthafrica.com. Afrikaans is naas Engels die enigste werkstale in höer howe. 
die noodwendige voorkeur van moedertaalonderrig by die verwerwing van regstaal. Moedertaalsprekers sukkel self met die aanleer van die regsvaktaal en soos Taylor ${ }^{59}$ aandui, is regstaalverwerwing nog moeiliker en onbegrypliker vir diegene wat die jargon vanuit ' $n$ addisionele taal moet benader. Dit geld uiteraard Afrikaanssprekendes. Hiermee word nie bedoel dat Afrikaanssprekendes vanuit die staanspoor slegs in Afrikaans moet praktiseer nie. Vanselfsprekend is twee- of meertaligheid die uiteindelike doelwit. Maar Afrikaanssprekendes sal regstaal sonder twyfel baie vinniger aanleer wanneer die individu dié jargon en taalkennis in sy/haar moedertaal verwerf. Die sukses van studies in die individu se moedertaal bo studies in ' $n$ addisionele taal is verskeie kere gemeet en aangeteken. ${ }^{60}$ Die gevolge van studies in ' $n$ addisionele taal "can be the failure to grasp the principles of law and more importantly the principles on which the law is based." ${ }^{11}$ Die noodsaaklikheid van 'n geletterdheidskursus in regstaal (en die aanbod van Afrikaans as vaktaal vir regstudente aan 'n tersiêre instansie) behoort by elke regs- en taalgeleerde persoon vanselfsprekend te wees.

\section{Gevolgtrekking}

Wanneer 'n mens met akademici in die veld van regsgeleerdheid of regsgeleerdes in die praktyk in gesprek tree, is dit ooglopend dat daar ' $n$ dringende behoefte aan regstaalkursusse is. Menige student en jong praktisyn sukkel om komplekse sinskonstruksies, veelvoudige betekenisse en retoriek in regstekste te begryp. Die opstel van regstekste, soos kontrakte en lasbriewe word dikwels nie bemeester nie. Foute sluip toenemend in regsdokumentasie in (vergelyk voorbeelde in onderafdeling 6). Die betrokke taalongeletterdheid gee derhalwe tot 'n aantal probleme aanleiding wat die regsproses kortwiek.

Taal is vir die juridiese kosmos van kardinale belang. Indien die administratiewe optrede of hofverrigtinge nie in die inidividu se moedertaal plaasvind nie, sal artikels 31(1)(a), 33, 34 en 35(2)(c) en (3) van die Grondwet boonop ondermyn word. Die

\footnotetext{
59 Taylor 1998 THRHR 670.

60 Vgl. onder meer Webb vir breedvoerige argumentasie ten gunste van moedertaalonderrig: Webb 2006 Tydskrif vir Geesteswetenskappe 37-50; asook Kazima vir studies aangaande moedertaalonderrig: Kazima 2008 Pythagoras 56-63.

61 Taylor 1998 THRHR 670.
} 
noodsaaklikheid van die onderrig van Afrikaans vir regstudente word hierdeur benadruk, want 'n gebrek aan hierdie opleiding mag veroorsaak dat toekomstige voorsittende beamptes, staatsprokureurs en ander regslui nie oor die nodige taalkennis sal beskik om aan bogenoemde artikels effek te gee nie.

Dit is ook van belang om te meld dat die gepaste aanwending van goeie regstaal inderwaarheid ook finansiële implikasies kan hê. Deur die taal van die kliënt te besig, dokumentasie in die kliënt se taal op te stel en deur met verskeie rolspelers in die kliënt se taal in gesprek te tree, kan die regsgeleerde finansieel daaruit voordeel trek. Dit geld nie net Afrikaans nie, maar elk van die elf ampstale. Gelyke beregtiging kan baie voordelig wees.

Die suksesvolle gebruik van regstaal is in talle opsigte van 'n regstaalkursus afhanklik. Geen regsgeleerde stap die praktyk sonder taalopleiding binne nie. Hoe taalvaardiger die regspraktisyn, hoe beter die moontlikheid op sukses. Afrikaans het derhalwe steeds ' $n$ rol binne die regsdomein te speel. Ten spyte van die oorheersende invloed en gevolglike bedreiging van Engels is Regsafrikaans steeds van groot belang vir Suid-Afrika se regspleging. 


\section{Bibliografie}

Bhatia 1987 Language Teaching

Bhatia VK "Language and the Law: State of the Art Article" 1987 Language Teaching 227-234

Christie Law of Contract

Christie HR The Law of Contract in South Africa 5th ed (Butterworths Durban 2006)

Cote Right to Language

Cote D The Right to Language Use in South African Criminal Courts (LLMverhandeling UK 2005)

Cunningham 2001 Tydskrif vir Taalonderrig

Cunningham D "Languages, Technology and Teaching: Challenges and Solutions for the 21st Century" 2001 Tydskrif vir Taalonderrig 201-222

Du Plessis en Pretorius 2000 SA Public Law

Du Plessis LT en Pretorius JL "The structure of the official language clause: a framework for its implementation" 2000 SA Public Law 505-526

Ehlers Afrikaans vir Regstudente

Ehlers D Afrikaans vir Regstudente (AFK103S-studiegids) (Unisa Pretoria 2008)

Grossfeld 1987 De Jure

Grossfeld B "Literature, Language and the Law" 1987 De Jure 217-226

Hiemstra 1970 Tydskrif vir Geesteswetenskappe

Hiemstra VG "Die opkoms van Afrikaans in die regspleging" 1970 Tydskrif vir Geesteswetenskappe 251-263 
Heuth "Disabling and Enabling"

Heuth K "Disabling and Enabling: Implications of Language Policy Trends in South Africa" in Mesthrie R (red) Language and Social History: Studies in South African Sociolinguistics (David Philip Kaapstad 1995) 319-328

Heugh 2002 Perspectives in Education

Heugh $\mathrm{K}$ "The case against bilingual and multilingual education in South Africa: Laying bare the myths" 2002 Perspectives in Education 171-196

Kazima 2008 Pythagoras

Kazima M "Mother Tongue Policies and Mathematical Terminology in the Teaching of Mathematics" 2008 Pythagoras 56-63

Kleyn en Viljoen Beginnersgids

Kleyn D en Viljoen F Beginnersgids vir Regstudente 2de uitg (Juta Pretoria 1998)

Koch en Burkett 2005 South African Journal of Higher Education

Koch $E$ en Burkett $B$ "Making the role of African languages in higher education a reality" 2005 South African Journal of Higher Education 1089-1107

Malan 2003 Tydskrif vir Regswetenskap

Malan JJ "Die gebruik van Afrikaans vir die notulering van hofverrigtinge gemeet aan demokratiese standaarde" 2003 Tydskrif vir Regswetenskap 3658

May 2000 Journal of Multilingual and Multicultural Development

May S "Uncommon Languages: The Challenges and Possibilities of Minority Language Rights" 2000 Journal of Multilingual and Multicultural Development 366-385

Mgoduso 1999 De Rebus

Mgoduso S "More on Language in the Practice of Law" 1999 De Rebus 8-9 
Morawetz Law and Language

Morawetz T Law and Language (Ashgate Aldershot 2000)

Nathan, Barnett en Brink Reëls en Gebruike van die Hooggeregshof

Nathan CJM, Barnett M en Brink A (vertaal deur Steyn GC) Reëls en Gebruike van die Hooggeregshof van Suid-Afrika: Eenvormige Reëls van die Provinsiale Afdelings en Appèlafdeling, saam met die Wet op die Hooggeregshof, 1959, alle ander ter sake dienende Wette en Volledige Kommentaar daarop (Juta Kaapstad 1965)

Pennycook 1998 Language Sciences

Pennycook A "The Right to Language: Towards a Situated Ethics of Language Possibilities" 1998 Language Sciences 73-87

Perry 2004 Ethnicities

Perry $T$ "The Case of the Toothless Watchdog: Language Rights and Ethnic Mobilization in South Africa" 2004 Ethnicities 501-521

Phaalha "Knowledge Production"

Phaalha PL "Knowledge Production in What Language? The Hegemonic Use of English as a Language of Commerce and Industry from a South African Perspective" in Arasanyin OF en Pemberton MA (reds) Selected Proceedings of the 36th Annual Conference on African Linguistics 2006 Somerville MA $142-154$

Rademeyer Beeld

Rademeyer A 'Staat moet help met dié tale' Beeld 9 Februarie 201015

Steyn Uitleg van Wette

Steyn LC Uitleg van Wette (Afrikaanse Pers-Boekhandel Johannesburg 1946) 
Taylor 1998 THRHR

Taylor DC "Addressing the Insane Language of Law" 1998 THRHR 668-677

Tollefson Planning Language

Tollefson J Planning Language, Planning Inequality: Language Policy in the Community (Longman Londen 1991)

Truter 2006 Literator

Truter E "Mediadekking in die Suid-Afrikaanse gedrukte media oor taalverwante onderwerpe, in besonder taalregte en taalbeleidskwessies" 2006 Literator 135-156

Van der Merwe 1975 Nuntius

Van der Merwe NJ "Die opkoms van Afrikaans in die Regswêreld" 1975 Nuntius 8-10

Van der Walt 1992 THRHR

Van der Walt $C$ "Teaching a Foreign Language: The Language of the Law" 1992 THRHR 94-102

Van Zijl Steyn Engels-Afrikaanse Regswoordeboek

Van Zijl Steyn I Engels-Afrikaanse Regswoordeboek (Nasionale Pers Kaapstad 1933)

Viljoen 1992 SALJ

Viljoen F "Look Who's Talking, in the Courtroom, too!" 1992 SALJ 64-76

Viljoen 1992 De Jure

Viljoen F "Die storie van Afrikaans as Regstaal" 1992 De Jure 439-446

Webb 2006 Tydskrif vir Geesteswetenskappe

Webb VN "Perspektiewe op moedertaalonderrig" 2006 Tydskrif vir Geesteswetenskappe 37-50 


\section{Register van wetgewing}

Grondwet van die Republiek van Suid-Afrika 110 van 1983

Grondwet van die Republiek van Suid-Afrika 200 van 1993

Grondwet van die Republiek van Suid-Afrika, 1996

Interpretasiewet 33 van 1957

Wet op Prokureurs 53 van 1979

\section{Register van staatspublikasies}

South African Languages Bill - AK 1514 in SK 24893 van 30 Mei 2003

\section{Register van hofsake}

Lategan v Union Goverment 1937 CPD 197

Lourens $v$ die President van die Republiek van Suid-Afrika (49807/09) [2010] ZAGPPHC 19 (16 Maart 2010)

Souter v Norris 1933 AD 41

\section{Register van internetbronne}

De Bruin 2010 www.nuus24.com

De Bruin P 2010 Afrikaans is op sy eie, sê staat www.nuus24.com/SuidAfrika/Nuus/Afrikaans-is-op-sy-eie-se-staat-20100208 [datum van gebruik 7 Feb 2010]

Du Plessis 2010 www.oulitnet.co.za

Du Plessis T 2010 'n Taalwet vir Suid-Afrika? Die rol van sosiolinguistiese beginsels by die ontleding van taalwetgewing www.oulitnet.co.za/akademies_geestes/pdf/LA_7_2_duplessis.pdf [datum van gebruik 27 Mei 2010] 
Den Hartigh 2009 www.mediaclubsouthafrica.com

Den Hartigh W 2009 African Languages in SA Courts www.mediaclubsouthafrica.com/index.php?option=com_content\&view=article \&id=1018:indigenous-languages-in-sa-courts\&catid=42:landnews \&ltemid $=110$ [datum van gebruik 10 Jun 2010]

Legalbrief Today 2009 www.legalbrief.co.za

Legalbrief Today 2009 Constitutional: Battle for Afrikaans in Top Court www.legalbrief.co.za [datum van gebruik 21 Aug 2009]

Malan 2009 www.vrs.co.za

Malan K 2009 Observations and suggestions on the use of the official languages in national legislation www.vrs.co.za [datum van gebruik 10 Jun 2010]

\section{Lys van afkortings}

SALJ

South African Law Journal

SA Public Law South African Public Law

THRHR Tydskrif vir Hedendaagse Romeins-Hollandse Reg 